практике вопрос о допустимости преодоления преюдиции при доказывании по уголовному делу остается неопределенным [9, с. 187].

В заключении, следует отметить, что несмотря на неоднозначность такого института как уголовно-процессуальная преюдиция, она все еще остается эффективным способом доказывания при разбирательстве по делу, помогая судам разрешать дела, соблюдая принципы законности, справедливости и всесторонности. Тем не менее, хотя законодательство и судебная практика еще не выработали необходимые инструменты для совершенствования данного института доказывания, суды продолжают использовать его, что еще раз подтверждает актуальность существования преюдиции в уголовном судопроизводстве. Из этого следует, что одним из путей решения данных проблем могут послужить тематические обзоры Верховного Суда Российской Федерации о применении статьи 90 УПК, а также Постановления Пленума, разъясняющие судам порядок применения преюдиции при рассмотрении судами уголовных дел. Более того, данный институт не отменяет то, что при вынесении приговора суд оценивают доказательства по своему внутреннему убеждению, руководствуясь только законодательством Российской Федерации и совестью.

$$
* * *
$$

1. Уголовный процесс: учебник / Под ред. Юношева С.В., Шуваткина А.В., Шестаково1 Л.А., Шейфера С.А., Тарана А.С., Савельева К.А., Развейкиной Н.А., Проскуриной Т.Ю. - М.: Юстиция, 2021. - 653 с.

2. Трофимов Д.В. Презумпции и преюдиция как правила доказывания в уголовном процессе // Наука и образование сегодня. 2018. №12 (35).

3. Головко Л. Преюдиция в уголовном процессе должна стать не помехой, а помощником правосудия» // Закон. 2015. № 8.

4. Постановление Конституционного Суда Российской Федерации от 21.12.2011 № 30-П «По делу о проверке конституционности положений ст. 90 УПК РФ в связи с жалобой граждан В.Д. Власенко и Е.А. Власенко (абз. 5 п. 3.1)» // Собрание законодательства РФ. 2012. № 2. Ст. 398.

5. Зотов Д.В. Преюдициальные судебные акты как необходимые пределы доказывания в уголовном судопроизводстве // Государство и право. 2017. № 3.

6. Азаров А. Неопровержимая преюдиция в уголовном процессе: за и против» // Закон. 2019. № 6.

7. Аристархов А.Л. О правилах общей и специальной преюдиции в российском уголовном процессе // Известия Тульского государственного университета. Экономические и юридические науки. 2020. № 2.

8. Меженина Е.В. Уголовно-процессуальная политика применения межотраслевой преюдиции в Российской Федерации // Сибирские уголовно-процессуальные и криминалистические чтения. 2017. №3 (17).

9. Лопатин С.А. Об опровержимом характере преюдиции в уголовном судопроизводстве Российской Федерации // Пробелы в российском законодательстве. 2017. №2.

\title{
Рябченко Н.Н. \\ Содержание и формы работы по лингвокраеведению в процессе обучения родному языку
}

ГБОУ ВО «Ставропольский государственный педагогический институт» (Россия, Ставрополь)

doi: 10.18411/lj-04-2021-168

\section{Аннотация}

В статье рассматриваются дидактические и воспитательные возможности лингвокраеведческого материала в школьной практике обучения родному языку. Автор раскрывает формы работы по лингвокраеведению, источники изучения языка и культуры родного края. Основное содержание исследования составляют анализ и описание работы с лингвокраеведческим материалом на уроках родного языка в школе.

Ключевые слова: лингвокраеведение, родной язык, ономастика, диалектная лексика. 


\section{Abstract}

The article deals with the didactic and educational possibilities of linguistic and local history material in the school practice of teaching the native language. The author reveals the forms of work on linguo-regional studies, the sources of studying the language and culture of the native land. The main content of the study is the analysis and description of the work with linguistic and local history material in the lessons of the native language at school.

Keywords: linguistics, native language, onomastics, dialect vocabulary.

Проблемы изучения языка тесно связаны с вопросами формирования гражданской идентичности и национального сознания обучающихся. Необходимость их решения не может не влиять на характер современных уроков родного языка в школе.

Лингвокраеведение занимает особое место в рамках обучения родному языку, поскольку является одним из средств реализации регионального компонента в учебновоспитательном процессе. По мнению многих ученых, непосредственными объектами исследования лингвокраеведения в ходе обучения родному языку могут выступать диалектная речь; местная ономастика; местный фольклор; язык художественных произведений писателей, биографически связанных с тем или иным краем, язык местных СМИ и местных исторических документов; речь местных жителей, городское и деревенское просторечие; местный речевой этикет; семейные родословные и др. [3].

Поскольку содержание курса «Родной язык» направлено на формирование представлений о языке как живом развивающемся явлении, то исследование диалектной лексики, фразеологии, а также фонетических и грамматических особенностей местного говора, местной ономастики, художественных произведений местных писателей будет содействовать более успешному овладению предметом.

Организация лингвокраеведческой работы в процессе изучения родного языка содействует формированию и развитию следующих важнейших умений и навыков обучающихся:

1) сведения о языке как культурно-историческом явлении, которое воплощает историю, обычаи и традиции региона;

2) способность анализировать окружающую речевую среду, оценивать и определять индивидуальные языковые явления в выступлении жителей региона;

3) умение сообщать свои мысли в аспекте региональной ориентации (природный, культурный и языковой характер региона);

4) возможность анализировать художественные произведения местных писателей, журналистов и т. д. [6].

Следует отметить, что дидактический потенциал лингвокраеведения в процессе обучения родному языку довольно высок. Введение краеведческого материала позволяет учитывать конкретно-образный характер мышления школьников. Опора на близкие и знакомые учащимся объекты материальной и духовной культуры родного края, его природу и т. п. способствует осмыслению обучающимися учебного материала, конкретизируя его; подводит школьников от близких, доступных непосредственному наблюдению фактов и явлений к формулировке глубоких выводов и обобщений; содействует активизации мыслительной деятельности и т.д. Более того, использование лингвокраеведческого материала на уроках создает благоприятные условия для осуществления интеграции и метапредметного подхода в системе обучения родному языку. 
Включение лингвокраеведческого материала в школьную практику обучения родному языку может осуществляться непосредственно на уроках при изучении тематики общеобразовательной программы.

К традиционным приемам формирования лингвокраеведческих знаний на уроках родного языка относятся:

- широкое использование в качестве дидактического материала разных групп слов с национально-культурным компонентом;

— ознакомительная работа с фразеологическими единицами, пословицами и поговорками и т.п., бытующими в крае;

— языковой анализ текстовых материалов, которые содержат информацию о культурно-историческом наследии народа того или иного региона [4, c. 34].

Содержательная сторона уроков родного языка с использованием лингвокраеведения отражает региональную специфику и сводится к следующему:

1) исследование местной ономастики;

2) знакомство с диалектными особенностями языка в крае.

Исследование местной ономастики - важнейший элемент работы на уроках родного языка в общеобразовательной школе. Ономастика служит отличным средством стимулирования интереса школьников к языку, расширяя их кругозор, содействуя углубленному усвоению знаний по различным дисциплинам, в частности, географии, истории, лингвистике.

Знакомство с ономастикой в процессе обучения родному языку можно организовать в различных формах. Например, выявление отличительных признаков между именами собственными (онимами) и нарицательными (аппелятивами), привлечение учащихся к исследовательской деятельности по изучению происхождения собственных имен в ходе внеурочной работы.

Как показала практика, большой познавательный интерес у учащихся вызывает знакомство с топонимами - разрядами онимов, т.е. именами собственными, обозначающими название природного объекта на Земле или объекта, созданного человеком.

Высокий потенциал топонимической лексики и возможностей ее использования на уроках русского языка в школе показаны в работах Г.Ф. Ковалева, Л.И. Луговой, Л. К. Лыжовой, В.Ф. Филатовой и др. Авторы отмечают, что изучение местной топонимии целесообразно начинать с 5 класса. Это обусловлено тем, что в этом возрасте ученики проявляют неподдельный интерес к родному слову, к местной истории, к народным легендам, связанным с происхождением того или иного географического названия.

На уроках родного языка привлечение к топонимам может быть эпизодическим. Так, к примеру, региональные топонимы могут использоваться при изучении имен собственных в рамках темы «Нормы орфографии». Но для более углубленной лингвокраеведческой работы целесообразно исследование региональной топонимии в процессе внеклассной деятельности. Топонимический материал может быть собран самими школьниками в ходе опроса местного населения или извлечения из письменных источников. Географические названия являются доступными для наблюдений и классификаций, в связи с этим под руководством учителя ученики могут достаточно быстро овладеть навыками лингвистического анализа топонимов.

Следует отметить, что особое место в процессе лингвокраеведческой работы занимает исследование микротопонимов - собственных имен мелких объектов, функционирующих в пределах микротерритории и известных узкому кругу людей, живущих вблизи именуемого микрообъекта. «Именно эта категория имен собственных, 
- как пишет Г.Ф. Ковалев, - наиболее уязвима. Уходят без возврата старые названия улиц, частей населенных пунктов, а ведь они многое могли бы рассказать» [2, с. 20].

Микротопонимический материал позволяет получить яркое представление о некоторых особенностях края - его географических (например, ландшафтных и рельефных), демографических, исторических, языковых и других данных. Микротопонимы многое сохранили из того, что в живой речи жителей того или иного региона не используется; в микротопонимах отражена народная память о тех или иных событиях, фактах, людях, с которыми связано возникновение названия географического микрообъекта. В силу своего своеобразия обозначенный пласт лексики представляет для учителя несомненный интерес.

Знакомство с диалектными особенностями языка в крае - еще один важный аспект в работе учителя-словесника. Идеи использования диалектной лексики в процессе изучения родного языка актуальны в условиях Ставропольского края, так как большая часть школ края - это школы в сельской местности, функционирующие в условиях диалектного окружения. Следовательно, это требует некоторой коррекции методики обучения родному языку с учетом местной языковой ситуации.

Как отмечает Л.Л. Касаткин, «обучая литературному языку, нельзя допустить, чтобы он вытеснил у детей тот язык, которым они владеют с детства, - местный говор...» [1, с. 25]. В ходе ознакомительной работы с особенностями говора учитель должен обеспечить не только усвоение элементарных знаний основных параметров региональных особенностей языка, но и организовать сопоставление (не противопоставлении) их с литературной нормой, выявить потенциальные возможности скрытой эстетики и характерной образности народной речи того или иного региона.

Целесообразно продемонстрировать ученикам, что речь диалектная - это не столько речь неграмотных людей, сколько своеобразный драгоценный пласт национального языка с собственными специфическими грамматической и эстетической системами, которые необходимо исследовать и изучать с целью пополнения речи литературной.

Формы «погружения» в стихию народной речи могут быть различными. Это в большей степени зависит от возможностей педагога и ареала, в котором пребывают учитель и учащиеся (город или сельская местность), этнолингвистической ситуации (русскоязычный регион, регион с преобладанием кавказских языков, смешанный регион) [3]. В частности, это могут быть уроки-путешествия в страну русских говоров, диалектологические экспедиции во время экскурсионных поездок. В ряде случаев целесообразно организовать диалектологические исследования на уроках. Для этого использовать лишь «Толковый словарь живого великорусского языка» В.И. Даля, из которого учащиеся могут извлекать и анализировать местную лексику (лексика, обозначающая типы местной одежды, пищи, различных предметов быта, особенности земледелия, обрядов, названия растений, животных и т.д.). Выборка диалектного материала и его последующее комментирование выступает основой для проектных работ обучающихся в дальнейшем.

Сказанное позволяет заключить, что ознакомительная и исследовательская работа с диалектной лексикой края сводится к выявлению случаев уместного употребления диалектных явлений в речевой деятельности учащихся, отбору языковых средств в зависимости от ситуации общения. В этом случае важно обратить внимание на речевое взаимодействие в условиях бытового общения с носителями говора; поиск этнических реалий, не имеющих эквивалентов в русском литературном языке; собственное монологическое высказывание (например, сочинение на местном материале); анализ текста художественного произведения, в процессе которого на уровне восприятия происходит обучение использованию диалектизмов как средств выразительности речи [5]. 
Таким образом, лингвокраеведение обладает богатейшим дидактическим потенциалом. Обращение к лингвокраеведческому материалу на уроках родного языка в школе активизирует познавательные интересы учащихся, создает положительный эмоциональный фон обучения.

$$
* * *
$$

1. Касаткин Л.Л. Русская диалектология. М., 2005. 283 с.

2. Ковалев Г. Ф. Ономастические исследования и изучение родного края // Воронежское лингвокраеведение. Межвузовский сборник научных трудов. Воронеж, 2005. №1. С.13-23.

3. Ковалев Г.Ф. Задачи лингвокраеведения в средней школе // Актуальные проблемы изучения и преподавания русского языка и литературы: сборник научных статей. Воронеж: Изд-во ВГПУ, 1996. С. 20-24.

4. Морева Н.А. Современная технология учебного занятия М.: Просвещение, 2007. 158 с.

5. Плешкова Т.Н. Бережное отношение к материнскому языку // Русская словесность. 2003. № 1. С. 41-45.

6. Филатова В.Ф. Лингвокраеведческая работа в школе // Воронежский краевед. Выпуск 1. Воронеж: ВГУ, 1991. С. 161-172.

\section{Сербина Л.И., Чехонацкая А.В. \\ Методические аспекты применения цифровых образовательных ресурсов в процессе самостоятельной работы при обучении математике}

ГБОУ ВО «Ставропольский государственный педагогический институт» (Россия, Ставрополь)

doi: 10.18411/lj-04-2021-169

\section{Аннотация}

Рассмотрены основные принципы самостоятельной работы и отличительные ее особенности организации при обучении математике. Обсуждается вопрос о использовании цифровых образовательных ресурсов как одного из методов повышающего эффективность реализации самостоятельной работы и самоконтроля знаний по математике. Проведен анализ современных цифровых образовательных ресурсов по математике и указаны их существенные методики особенности,

Ключевые слова: теория обучения, навыки самообразования, обязательная самостоятельная работа, самоконтроль, цифровые образовательные ресурсы, управляемые самостоятельные работы, тестирование, инновационные методы обучения.

\section{Abstract}

The basic principles of independent work and its distinctive features of the organization in teaching mathematics are considered. The issue of the use of digital educational resources as one of the methods that increases the effectiveness of the implementation of independent work and self-control of knowledge in mathematics is discussed. An analysis of modern digital educational resources in mathematics is carried out and their essential techniques are indicated, features,

Keywords: learning theory, self-education skills, compulsory independent work, selfcontrol, digital educational resources, guided independent work, testing, innovative teaching methods.

Обучение в широком смысле слова - это процесс формирования готовности обучаемых к определенной самостоятельной деятельности на основе вновь приобретенного знания и индивидуального практического опыта. Процесс обучения представляет собой не только систему сообщения и усвоения определенных знаний, но также не менее значимую систему формирования познавательных способностей и 